\title{
CANA ENERGIA E PRODUÇÃO DE SILAGEM COMO ESTRATÉGIA PARA
} ALIMENTAÇÃO ANIMAL

\author{
Vanderli Luciano da Silva ${ }^{1}$ \\ Paulo Vitor Divino Xavier de Freitas ${ }^{1}$ \\ Graciele Araújo de Oliveira Caetano ${ }^{1}$ \\ Aldi Fernandes de Souza França ${ }^{1}$
}

\begin{abstract}
RESUMO
Apesar da dimensão de área para produção de gramíneas, existem variações na sua produção e qualidade ao longo do ano (sazonalidade), o que afeta diretamente a produção animal no Brasil. Isso faz com que os produtores busquem alternativas que amenizem esses efeitos. Uma delas é o cultivo da cana de açúcar, visto que se trata de um alimento com grande potencial para a alimentação de ruminantes. Novos cultivares são promissores para o setor, como é o caso da cana energia, uma variedade desenvolvida a partir do cruzamento de espécies ancestrais e híbridas comerciais de cana de açúcar. Suas maiores vantagens são a flexibilidade, podendo ser cultivada em áreas com baixa aptidão agrícola e sua alta produção de biomassa por unidade de área, superando os cultivares tradicionais. A cana de açúcar mantém seu valor nutricional durante os meses de inverno, sendo tradicionalmente fornecida fresca aos animais. A ensilagem tem sido utilizada para evitar as operações diárias de corte e transporte da cana e pode colaborar para o aumento da produtividade e vida útil dos canaviais pela maior eficiência nos cuidados pós-colheita, como capina e fertilização. Serve ainda para evitar a perda total da forragem em casos de incêndio ou de geadas.
\end{abstract}

Palavras-chave: conservação, produção de ruminantes, sazonalidade, volumoso.

\section{CANE ENERGY AND SILAGE PRODUCTION AS A STRATEGY FOR ANIMAL FEED}

\begin{abstract}
Despite the size of the area for grass production, there are variations in its production and quality throughout the year (seasonality), which directly affects animal production in Brazil. This causes producers to look for alternatives that mitigate these effects. One is the cultivation of sugar cane, as it is a food with great potential for feeding ruminants. New cultivars are promising for the sector, as is the case of energy cane, a variety developed from the crossing of ancestral and commercial hybrid sugarcane species. Its greatest advantages are its flexibility, which can be cultivated in areas with low agricultural suitability and its high biomass production per unit area, surpassing traditional cultivars. Sugar cane maintains its nutritional value during the winter months and is traditionally supplied fresh to animals. Silage has been used to prevent daily sugarcane harvesting and transport operations and can contribute to increased productivity and useful life of sugarcane by improving post-harvest care, such as weeding and fertilization. It also serves to prevent total loss of fodder in the event of fire or frost.
\end{abstract}

Keywords: conservation, ruminant production, seasonality, roughage.

\footnotetext{
${ }^{1}$ Universidade Federal de Goiás Correspondência: paulovitor_freitas@ hotmail.com 


\title{
PRODUCCIÓN DE ENERGÍA Y ENSILAJE DE CAÑA COMO ESTRATEGIA PARA LA ALIMENTACIÓN DE ANIMALES
}

\begin{abstract}
RESUMEN
A pesar del tamaño del área para la producción de pasto, hay variaciones en su producción y calidad durante todo el año (estacionalidad), lo que afecta directamente la producción animal en Brasil. Esto hace que los productores busquen alternativas que mitiguen estos efectos. Uno de ellos es el cultivo de la caña de azúcar, ya que es un alimento con gran potencial para alimentar a los rumiantes. Los nuevos cultivares son prometedores para el sector, como es el caso de la energía de la caña, una variedad desarrollada a partir del cruce de especies híbridas ancestrales y comerciales de caña de azúcar. Sus mayores ventajas son la flexibilidad, que puede cultivarse en áreas con baja idoneidad agrícola y su alta producción de biomasa por unidad de área, superando a los cultivares tradicionales. La caña de azúcar mantiene su valor nutricional durante los meses de invierno, siendo tradicionalmente suministrada fresca a los animales. El ensilaje se ha utilizado para evitar las operaciones diarias de cortar y transportar la caña y puede contribuir al aumento de la productividad y la vida útil de los campos de caña a través de una mayor eficiencia en el cuidado posterior a la cosecha, como el desmalezado y la fertilización. También sirve para evitar la pérdida total de forraje en caso de incendio o heladas.
\end{abstract}

Palabras clave: conservación, producción de rumiantes, estacionalidad, forraje.

\section{INTRODUÇÃO}

O Brasil se destaca pela sua alta produção agropecuária bem como pela sua capacidade e potencial de expansão, tornando-se um dos maiores produtores de alimento do mundo (1). A produção de bovinos no Brasil se dá basicamente à base de pasto e, o método que predomina é extensivo ou semiextensivo, com pastagens naturais ou cultivadas. Nestes sistemas, a produtividade animal é reduzida em função da quantidade e qualidade de pastagens oferecidas durante todo o ano (2).

A sazonalidade na produção de gramíneas forrageiras acontece em função da existência de dois períodos bem distintos durante o ano: verão e inverno. No verão as condições climáticas são ideais (luminosidade, precipitação pluviométrica e temperatura) o que proporciona uma oferta de forragem de até $80 \%$ do total da produção anual, já no inverno as condições são menos favoráveis o que reduz a disponibilidade e qualidade das plantas forrageiras (baixa precipitação pluviométrica, queda da luminosidade e queda de temperatura), esses são os principais fatores que afetam a produtividade da pecuária com queda na produção de carne e leite (3).

Diante dessas adversidades e estacionalidade de produção das gramíneas forrageiras tropicais, o planejamento alimentar dos rebanhos se torna imprescindível. Existem várias formas de reduzir os impactos produtivos, dentre eles, os processos de conservação de forragens, como ensilagens, fenação e manejos diferidos de pastagens (4).

Aqui será destacado a produção de silagem, que apesar de difundida nem sempre é produzida da melhor forma. A ensilagem envolve o armazenamento de forragens em condições de anaerobiose, com o desenvolvimento de bactérias ácido láticas que fazem a conversão de carboidratos solúveis, ácidos orgânicos e compostos nitrogenados solúveis em ácido lático. Esse processo provoca a queda no $\mathrm{pH}$ da massa ensilada a níveis que inibem a atividade microbiana, aumento da temperatura e nitrogênio amoniacal, preservando assim as características na massa ensilada (5). 
Para se obter silagens de boa qualidade é necessário observar alguns fatores como umidade do material (ideal em torno de 35\% de MS), os teores de carboidratos solúveis e o poder tampão. Vale ressaltar que quando estiverem fora dos padrões ideais esses devem ser corrigidos. Várias técnicas têm sido recomendadas para que se corrijam as restrições, dentre elas o emurchecimento da forragem antes da ensilagem, a utilização de aditivos absorventes de umidade e/ou químicos, o uso de inoculantes bacterianos e inibidores de fermentação (6).

Algumas culturas como a do milho por si já apresentam características desejáveis para o processo de fermentação e conservação em forma de silagem, já outras como a cana de açúcar necessitam de adequações, as quais não reduzem o seu potencial para utilização na forma de silagem. A conservação da cana de açúcar na forma de silagem tem despertado grande interesse nos produtores, pesquisadores e agroindústrias que trabalham com a cultura, em virtude de seus benefícios em logística e operacionalidade.

A cana de açúcar é amplamente utilizada como forragem suplementar de inverno no Brasil e em outros países de clima tropical, sendo utilizada também como volumoso principal em fazendas produtoras de leite e em confinamentos de gado de corte. A cana de açúcar é uma forrageira com grande potencial de produção de MS e energia por área e permite bom desempenho dos animais quando corretamente suplementada com proteínas e minerais. É importante lembrar que existem várias cultivares de cana, algumas mais adaptadas outras não (7). No entanto destaca-se aqui a cana energia, cultivar que vem surgindo como uma alternativa frente à cana convencional, sendo resultado do cruzamento de ancestrais e híbridos comerciais. Esta pode ser cultivada em áreas marginais, solo mais pobre, regiões de clima instável, é mais robusta e altamente produtiva. Apresenta sistema radicular mais abundante e vigoroso e tem maior capacidade de produzir rizomas, o que confere maior tolerância ao déficit hídrico e rusticidade. Porém apresenta um teor mais elevado de fibras, motivo pelo qual tem se difundido na geração de energia (8).

Como citado anteriormente, a cana de açúcar apresenta algumas limitações para confecção de silagens, entretanto aditivos químicos e microbianos têm sido utilizados para evitar o desenvolvimento de leveduras, acelerar ou reduzir os processos fermentativos, absorver umidade ou até mesmo melhorar a eficiência de estabilidade aeróbica da silagem de cana. A ureia, o hidróxido de sódio e o óxido de cálcio podem melhorar a qualidade dessa silagem, diminuir a população de leveduras e mofos, reduzir a produção de etanol, diminuir as perdas de MS e de carboidratos solúveis. Outra opção é a utilização de inoculantes bacterianos na ensilagem de cana de açúcar, no entanto esses tem promovido resultados variáveis (9).

Diante do exposto, objetivou-se com esta revisão abordar sobre a importância da cana de açúcar, em especial a "Cana energia" (Saccharum spontaneum) e processos de ensilagem desses materiais para alimentação animal.

\section{REVISÃO DE LITERATURA}

\section{Sazonalidade da produção forrageira}

Apesar das condições auspiciosas e da dimensão de área para produção de gramíneas existem variações na produção e qualidade ao longo do ano, o que por consequência afeta diretamente a produção animal no Brasil Central. Essa sazonalidade afeta a produção, fazendo com que os produtores busquem alternativas que amenizem esses efeitos, afim de garantir uma maior produtividade e retorno econômico ao longo do ano (10).

Em função da existência de dois períodos climáticos bem distintos (sazonalidade) durante o ano (verão e inverno), a produção de gramíneas forrageiras na parte central do Brasil é afetada. $\mathrm{O}$ verão apresenta características climáticas ideais, com luminosidade (foto 
período), precipitação pluviométrica (umidade) e temperatura (calor) que favorecem o crescimento das plantas forrageiras tropicais (3). Já no inverno, as adversidades climáticas tais como baixa precipitação pluviométrica, queda da luminosidade, redução de temperatura e estádio de maturação/fisiológico das forrageiras avançado diminuem a produtividade das gramíneas e reduzem o seu valor nutritivo (11).

A redução da disponibilidade e qualidade das forragens afetam a produtividade da pecuária e provoca quedas na produção de carne e leite. Sendo assim fica claro a necessidade de se desenvolver técnicas ou práticas agropecuárias que minimizem esse déficit de massa verde (MV) em determinadas épocas do ano.

Uma das alternativas encontradas por pecuaristas é realizar o armazenamento dessa forragem que se encontra em abundância no período chuvoso, para posterior utilização no período de estiagem quando essas se encontram em menor disponibilidade (12).

Uma técnica eficiente para esse armazenamento é a ensilagem da planta forrageia. Esse processo que consiste em triturar a massa verde em partículas entre 1-3 cm de comprimento, armazenar em ambiente fechado para que ocorra uma fermentação anaeróbica permite que o material seja guardado por períodos mais longos e possa ser fornecido aos animais quando houver a queda na produção da pastagem natural (13).

\section{“Cana energia" (Saccharum spontaneum)}

Os programas de melhoramento da cana em diversos países do mundo, inclusive o Brasil tem procurado realizar melhorias da cultura em função do objetivo de seu uso. Em busca de melhores variedades desenvolveu-se a cana energia, também conhecida como energycane, desenvolvida para geração de energia, visto sua alta capacidade produtiva de biomassa. Os clones desse material têm em geral menor teor de sacarose e maior teor de fibras totais, porém, a alta produção de biomassa total é sempre o primeiro fator a ser considerado (14).

A cana energia é uma variedade desenvolvida a partir do cruzamento de espécies ancestrais e híbridas comerciais de cana de açúcar. O resultado é uma cana mais robusta, com maior teor de fibra e potencial produtivo, ideal para fabricação de biocombustíveis e bioquímicos de segunda geração e para geração e/ou cogeração de energia elétrica (8). Em função da sua alta produtividade de biomassa a cana energia tem potencial para produzir muito mais açúcares celulósicos por hectare que as variedades convencionais. Matsuoke et al. (8) explicitaram os caminhos pelos quais a cana energia foi obtida. A partir de um programa de melhoramento genético da cana de açúcar tradicional, inicialmente idealizado em Porto Rico, no final da década de 1970 começaram as tentativas para obtenção de um material com elevados teores de celulose, hemicelulose e lignina. Para isso, recorreu-se a utilização de variedades mais rusticas de cana de açúcar. Exemplares da espécie Saccharum officinarum foram cruzados com exemplares de Saccharum spontaneum, que naturalmente já apresenta um alto teor de fibra.

Uma de suas maiores vantagens é sua flexibilidade, podendo ser cultivada em áreas com baixa aptidão agrícola. Isso permite a exploração de regiões desfavorecidas, o aumento da produtividade por hectare não competindo com a produção de alimentos (15). Suas principais características é uma maior quantidade de fibra (>18\%), rusticidade, rebrotação na soca e facilidade na reprodução bem como raízes mais fortes e melhor resistência ao déficit (8).

A cana energia apresenta algumas características que a distinguem da cana de açúcar tradicional: a cana energia apresenta uma lamina de folha mais estreita, uma haste mais fina e um perfilhamento mais profuso, além disso, permite ainda um maior número de colheitas graças ao rizoma de $S$. spontaneum, uma característica que os criadores pioneiros da cana de 
açúcar procuraram nesta espécie, em contraposição a vulnerabilidade da espécie $S$. Officinarum (8).

Foram sistematizadas as principais características das novas variedades obtidas de cana energia (16). Diferentemente da cana de açúcar comum que apresenta declínio na produção a partir do primeiro corte, na cana energia a touceira vai perfilhando em decorrência dos rizomas e mantem sua produtividade, sendo assim expectativa em relação à longevidade do canavial é de 10 anos. Como o genoma da cana energia tem maior participação de ancestrais rústicos, ela e mais resistente as doenças que a cana de açúcar comum, podendo ser cultivada em áreas mais restritas como ambientes degradados (15).

A cana energia é uma alternativa para áreas em que o plantio da cana convencional, visto sua maior produtividade em suco, açúcar, bagaço e biomassa (17). Se considerarmos o elevado potencial produtivo (figura 01 e 03) e que o Brasil apresenta 32 milhões de hectares de pastagens degradadas está pode ser uma opção para suplementação alimentar para o rebanho. Entretanto ainda não há trabalhos voltados para a nutrição animal com a cana energia. Sendo assim, faz-se necessário conhecer a capacidade produtiva da forragem, o valor nutricional e as características de degradação ruminal da forrageira garantindo assim maior assertividade no atendimento das necessidades nutricionais dos animais.

\section{Utilização da cana de açúcar na produção animal}

A grande adoção da cana de açúcar como volumoso suplementar para a seca baseia-se na facilidade e na tradição de cultivo, sobretudo por consistir-se em opção competitiva quando comparada a outras forrageiras. Em simulações de sistemas de produção animal (ruminantes) a cana vem surgindo como uma das opções mais interessantes para a minimização dos custos de rações e maximização da projeção da receita líquida da atividade (18).

A alta produtividade de massa verde (80 a 120 t/ha), o baixo custo por unidade de matéria seca (MS), a manutenção do valor nutritivo até seis meses após a maturação, o período de colheita coincidente com o período de escassez de pastagens (19), aliados à facilidade de obtenção de mudas para plantio e à possibilidade de atingir taxas de ganhos de peso razoáveis têm atraído os pecuaristas para a utilização da cana de açúcar como alimento volumoso para bovinos.

Apesar de altamente produtiva, a cana de açúcar possui algumas limitações quando fornecidas aos animais, entre elas o baixo conteúdo de proteínas (inferior a 7\%) e minerais. Sendo assim faz-se necessário a complementação com ureia (nitrogênio não proteico com baixo custo) e minerais no cocho, visto que ruminantes alimentos com teor de PB inferiores a $7 \%$ tem a atividade dos microrganismos ruminais reduzidas, o que desfavorece a microbiota do rúmen e compromete a utilização dos compostos fibrosos da forragem (20).

Outro fator limitante na utilização da cana de açúcar é a baixa digestibilidade da fibra. O teor de lignina pode ser considerado como o principal fator da planta envolvido na redução da sua digestibilidade (21). Esses fatores são fisiológicos das plantas e geralmente estão envolvidos na sua proteção contra a predação e biodegradação.

Considerando os fatores limitantes da cana de açúcar na alimentação animal, cabe decidir como essa será fornecida aos animais. Existem duas formas muito utilizadas, uma é a colheita da cana fresca in natura no momento do trato dos animais ou a confecção de silagem para posterior fornecimento (6). A cana de açúcar colhida diariamente e oferecida fresca aos animais é uma prática tradicional de amplo conhecimento de pecuaristas, porém o manejo industrial de canaviais exige que o corte dos talhões seja realizado de forma concentrada, para aumentar a eficiência dos tratos culturais. Além disso o corte diário torna-se problemático em situações nas quais se deseja utilizar a cana como forrageira durante todo o ano, isso em razão 
da dificuldade de sua colheita em dias de chuva e à perda no seu valor nutritivo durante o verão. Canaviais que tenham sido submetidos à queima ou que tenham sofrido fortes geadas também requerem utilização rápida, para não serem perdidos.

A silagem de cana de açúcar é uma ótima alternativa, no entanto esse processo é delicado e precisa ser esclarecido. Durante a ensilagem pode ocorrer intensa atividade de leveduras o que transforma os açúcares em etanol, água e dióxido de carbono. Isso reduz os teores de açúcares e carboidratos solúveis da silagem e consequentemente aumento dos componentes da parede celular, ocasionando perdas de qualidade do material (22). Porém existem técnicas que evitam esse tipo de acontecimento, uma delas é a utilização de aditivos/inoculantes que visa manter e/ou melhorar a qualidade e reduzir perdas.

Uma boa opção para melhorar o valor nutritivo de alimentos volumosos com elevado teor de fibra como silagem de cana energia, é o tratamento químico, como o $\mathrm{NaOH}$ e $\mathrm{CaO}$ (23).

\section{Silagem}

A utilização da tecnologia de conservação de forrageiras tropicais tem sido uma das alternativas encontradas pelos pecuaristas para minimizar a sazonalidade na produção de forrageiras para o rebanho no período de escassez. Define-se como silagem a forragem verde, suculenta, conservada por meio de um processo de fermentação anaeróbica, essas são armazenadas em estruturas chamadas silos. Já o processo de cortar a forragem, colocá-la no silo, compactá-la e protegê-la com a vedação do silo para que haja a fermentação recebe o nome de ensilagem (24). Essa silagem é um alimento volumoso usada principalmente para ruminantes na época seca, ou em confinamentos pois pode substituir o pasto. Os processos de produção se dividem em uma fase aeróbica e outra anaeróbica.

A fase aeróbica ocorre durante a colheita e enchimento do silo se prolongando até poucas horas depois do fechamento do silo (o fechamento deve ser o mais rápido possível). A planta é cortada ainda verde, isso faz com que ela continue respirando, contribuindo juntamente com as bactérias na redução do oxigênio do meio (25). Grandes quantidades de oxigênio favorecem o crescimento de microrganismos aeróbicos como fungos, leveduras e algumas bactérias anaeróbicas do gênero Clostridium que atuam na fermentação indesejada na silagem.

Possíveis atrasos nos processos de ensilagem ou falha na compactação do material ensilado prolongam a respiração da planta e favorecem o desenvolvimento das bactérias do gênero Clostridium em detrimento das bactérias ácido-láticas, o que diminui a quantidade de ácido lático produzido e impede a queda do $\mathrm{pH}$. Isso faz com que haja o aumento de temperatura, a qual pode levar a mudanças químicas extensas nas proteínas com a condensação entre um grupo carboxílico da redução dos açucares com um grupo amina livre de um aminoácido ou proteína, denominadas reações de Maillard, ou seja, quanto maior for a temperatura maiores serão os danos na fração proteica da silagem e maior escurecimento da massa ensilada (26).

$\mathrm{Na}$ fase de anaerobiose a ausência de oxigênio favorece o desenvolvimento de bactérias ácido láticas que fazem a conversão de carboidratos solúveis, ácidos orgânicos e compostos nitrogenados solúveis em ácido lático, processo que provoca queda no $\mathrm{pH}$ da massa ensilada a níveis que inibem a atividade microbiana evitando o aumento da temperatura e do nitrogênio amoniacal preservando assim as características na massa ensilada (27).

$\mathrm{Na}$ fase de fermentação (após fechamento do silo) ocorre queda acentuada do pH da silagem devido à formação de ácidos orgânicos, a partir de açúcares. Inicialmente atuam enterobactérias e bactérias heterofermentativas, como Lactococcus lactis, Enterococcus faecalis, Pediococcus acidilactici, Leuconostoc mesenteroides e lactobacilos como os $L$. 
plantarum, L. Cellobioses, que crescem juntamente com microrganismos aeróbicos, como as leveduras, fungos e bactérias aeróbicas. Posteriormente com a redução de oxigênio tornam-se dominantes as homofermentativas (bactérias produtoras de ácido lático BAL) como lactococcus e lactobacillus. Esta fase se prolonga até que o $\mathrm{pH}$ decresça para valores abaixo de 5,0, sendo que o ideal para silagens bem preservadas a faixa de $\mathrm{pH}$ varia de 3,8 a 4,2 (25). É importante ressaltar que as características inerentes da planta a ser ensilada como matéria seca (teores acima de 20\%), a flora epífita e carboidratos solúveis são importantes ao processo.

Parâmetros como perdas por gases e efluentes e o índice de recuperação de matéria seca caracterizam bem o processo (26). Estas conclusões são feitas, avaliando concomitantemente as variáveis químicas e físicas como a estrutura da forragem, o tamanho da partícula, a compactação e população autóctone de bactérias láticas (29). A perda por gases está associada ao tipo de fermentação que ocorre durante o processo. Quando a fermentação ocorre por bactérias homofermentativas a glicose é utilizada como substrato e produzirá ácido lático, promovendo perdas menores. Todavia, quando a fermentação se dá por bactérias heterofermentativas, é produzido gás carbônico ( $\mathrm{CO} 2)$, etanol e manitol culminando em significantes perdas por gases.

Ao final de todo o processo a silagem tem a queda do $\mathrm{pH}$ e se encontra em condição de anaerobiose atinge a estabilidade e é conservada até a abertura do silo. Nesta fase, somente as bactérias ácido-lácticas se encontram em atividade, porém muito reduzida (30). Análises de nitrogênio amoniacal permitem concluir se o processo fermentativo foi satisfatório e se a massa ensilada manteve seu valor nutricional (25). Os teores de $\mathrm{N}-\mathrm{NH} 3 / \mathrm{NT}$ são bons indicativos da qualidade da silagem, visto que quando inferiores a $10 \%$, este indica que a silagem apresenta boa qualidade, pois a fermentação não resultou em quebra excessiva da proteína em amônia (31).

\section{Silagem de cana de açúcar}

Embora a cana de açúcar seja um alimento com grande potencial para a alimentação de ruminantes, seu uso na forma de silagem não é comum nos atuais sistemas de produção. A cana de açúcar mantém seu valor nutricional durante os meses de inverno, sendo tradicionalmente fornecida fresca aos animais. A ensilagem tem sido utilizada para evitar as operações diárias de corte e transporte da cana e pode colaborar ainda para o aumento da produtividade e da vida útil dos canaviais pela maior eficiência nos cuidados pós-colheita, como capina e fertilização. Serve ainda para evitar a perda total da forragem em casos de incêndio ou de geadas.

Um levantamento (32) sobre as práticas de produção e uso de silagem em fazendas produtoras de leite revelou que a silagem de cana de açúcar representa apenas $19 \%$ do total das silagens produzidas em todo o país. Ao se considerar a possibilidade de ensilagem da cana de açúcar deve-se levar em conta a intensa atividade de leveduras que convertem os açúcares da forragem a etanol, $\mathrm{CO} 2$ e água, visto que esta apresenta fermentação tipicamente alcoólica. Teores de etanol de 8 a 17\% da matéria seca têm sido relatados em cana de açúcar ensilada sem o uso de aditivos, acompanhados por perdas gasosas de até 15,9\% da MS (33) e perdas totais de MS de até 32,5\% (34). Este tipo de fermentação pode causar reduções de 44 a $68 \%$ no teor de açúcares, aumento relativo nos componentes da parede celular e redução de $28 \%$ na digestibilidade da cana de açúcar assim conservada (33).

Vários aditivos têm sido utilizados na ensilagem de cana de açúcar e os resultados têm sido bastante variáveis (9). Mudanças na rota de fermentação das silagens mediante aplicação de aditivos podem alterar a composição final do alimento (35) e afetar o consumo de MS e a digestão de nutrientes em ruminantes (36). Silagens de cana de açúcar apresentam também 
intensa atividade de leveduras que convertem açúcares a etanol, óxido de carbono e água, causando reduções de até $70 \%$ no teor de carboidratos solúveis (CHO's), aumento nos componentes da parede celular e perdas de MS (33).

\section{Qualidade de silagem}

Estudos que visam reduzir a fermentação alcoólica e perdas durante o processo de fermentação em silagem de cana de açúcar $(13,37,38)$, por exemplo, o uso de aditivos químicos na ensilagem, podem contribuir para obter um volumoso de melhor qualidade com maior potencial nutritivo para nutrição de ruminantes. É interessante que as silagens apresentem baixos níveis de fibra em detergente neutro (FDN) devido à sua correlação com a ingestão de matéria seca (29).

Estudos conduzidos para avaliar a qualidade nutricional da silagem de cana de açúcar, revelaram elevados valores para a perda de MS durante a fermentação: 31,1 e 29,2\%, respectivamente $(9,33)$. Avaliando as perdas de silagens de cana de açúcar tratadas com aditivos químicos e bacterianos, Siqueira et al. (34) afirmaram que alguns fatores podem estar relacionados com a maior ou menor produção de efluentes. O primeiro relacionado é a picagem do material, pois, apesar de não ter sido quantificada no presente trabalho, fragmentos muito pequenos ocasionam maior produção de efluentes.

Outro fator que pode superestimar a produção de efluentes é o processo de ensilagem em silos experimentais de PVC, haja vista que os bastões de ferro utilizados na compactação da forragem apresentam diâmetro próximo ao dos silos, o que proporciona uma compactação sobre toda sua superfície, podendo provocar maior dilaceração das partículas ensiladas, tendo como consequência maior produção de efluentes. A produção e consequente escoamento de efluentes dependem de vários fatores, entre eles o teor de matéria seca da planta, a pressão de compactação e a forma e o tamanho do silo (39). Estes efluentes contêm grandes quantidades de compostos orgânicos, tais como açúcares, ácidos orgânicos e proteínas (25), assim, a redução dessas perdas resulta em maior teor de nutrientes na silagem.

\section{Utilização de Aditivos na silagem}

Com o intuito de melhorar os padrões de fermentação da silagem de cana de açúcar, diversos tipos de aditivos vêm sendo testados para que a ensilagem de cana de açúcar seja uma alternativa viável e rentável. Portanto, é neste cenário onde inúmeros aditivos químicos vêm sendo pesquisados com a finalidade de controlar a população de leveduras e de propiciar a redução das perdas decorrentes dos processos fermentativos. As pesquisas desenvolvidas tem permitido a inclusão de aditivos para inibir a fermentação alcoólica característica desse material. A produção deste álcool representa perda de aproximadamente $49 \%$ de MS dos substratos. Essa perda é composta principalmente de carboidratos solúveis, embora a perda em energia seja minimizada pela elevada concentração energética no etanol (25).

Os aditivos para silagem são classificados em cinco categorias (25): 1) os estimulantes da fermentação, ricos em carboidratos e estimula a proliferação das bactérias lácteas; 2) os inibidores da fermentação, diminuem o crescimento dos microrganismos, como o ácido fórmico; 3) os inibidores da deterioração aeróbica, que controlam a deterioração da silagem quando exposta ao ar, como o ácido propiônico e ureia; 4) os nutrientes que são adicionados às forragens ensiladas objetivando melhorar seu valor nutritivo; 5) e os absorventes de umidade, que são produtos com alto teor de MS, que atuam na absorção de umidade da forragem evitando o desenvolvimento de clostrídios e perdas por efluentes. Quando se opta por aditivos devem ser considerados o teor de matéria seca, a quantidade de carboidratos 
solúveis, a capacidade de absorção de água, a aceitabilidade, a facilidade de manipulação, a disponibilidade e o custo de aquisição.

\section{Hidróxido de Sódio $(\mathrm{NaOH})$}

$\mathrm{O} \mathrm{NaOH}$ é um aditivo que apresenta possibilidade de uso na ensilagem de cana de açúcar. Esse aditivo foi avaliado e recomendado para ser utilizado na ensilagem da cana de açúcar, pois foi capaz de alterar a fermentação alcoólica para fermentação predominantemente lática (9).

Substâncias fortemente alcalinas também modificam o processo de fermentação das silagens. Silagens de cana de açúcar tratadas com 3 a $4 \%$ de $\mathrm{NaOH}$ sobre a massa fresca (MF) apresentaram melhor composição bromatológica, redução acentuada na produção de etanol (5,2\% para $0,9 \%$ da MS), maior teor de ácido lático e maior digestibilidade da MS, o que resultou em maior consumo e ganho de peso em comparação a silagens produzidas sem aditivos.

\section{Óxido de Cálcio (CaO)}

A utilização do $\mathrm{CaO}$ na ensilagem da cana de açúcar tem como objetivo controlar o crescimento de leveduras em condições anaeróbias em função do aumento dos valores de $\mathrm{pH}$ e da pressão osmótica, o que, consequentemente, altera a população de microrganismos (34). Os mesmos autores, em revisão sobre o uso de aditivos alcalinos, constatou que esses aditivos podem neutralizar parcialmente os ácidos orgânicos, aumentando o tempo de fermentação e favorecendo a produção de ácidos durante a fermentação.

\section{Ureia}

A adição de ureia na ensilagem baseia-se na transformação dessa ureia em amônia (NH3), que reage com água formando hidróxido de amônia e eleva o pH que atua sobre o metabolismo de microrganismos indesejáveis, principalmente leveduras (40).

A ureia, quando em contato com a forragem ensilada, é hidrolisada a amônia, que tem efeito inibidor sobre a população de leveduras e mofos. Esta tem se mostrado capaz de reduzir a produção de etanol e as perdas de MS e de CHO's em silagem de cana de açúcar (41). Utilizando 0,5 a $1,5 \%$ de ureia propiciaram bom padrão de fermentação e melhor composição bromatológica, alcançando teores mais elevados de MS e menores concentrações de FDA e FDN (42). Aditivos químicos como a ureia e o hidróxido de sódio $(\mathrm{NaOH})$ podem melhorar a qualidade de silagens de cana de açúcar, diminuir a população de leveduras e mofos e reduzir a produção de etanol e as perdas de MS e de carboidratos solúveis.

\section{Lactobacillus plantarum}

A utilização de bactéria na ensilagem da cana de açúcar resulta em melhor recuperação de MS, redução na produção de etanol e aumento da estabilidade aeróbia das silagens, além de aumento no consumo e no ganho de peso em bovinos (36).

$O$ uso de inoculantes bacterianos na ensilagem de cana de açúcar tem promovido resultados variáveis. A inoculação de bactéria homolática (Lactobacillus plantarum) tem ocasionado elevação nas perdas de MS e na produção de etanol (9), uma vez que o ácido lático é usado como substrato por leveduras (25).

A utilização de bactérias heteroláticas em silagens tem sido mais eficiente no controle de populações de leveduras, contribuindo assim nas reduções de fermentação alcóolica e 
consequentemente na melhoria pós-abertura do silo, na estabilidade aeróbica das silagens analisadas com diferentes forrageiras.

\section{CONSIDERAÇÕES FINAIS}

Por se tratar de uma cultura altamente produtiva, fica evidente a importância da cana de açúcar para a pecuária brasileira, seja para fornecimento in natura seja para confecção de silagem. A adoção de tecnologias pode auxiliar na expansão de sua utilização. Como exemplo tem-se o desenvolvimento de novos cultivares, como é o caso da cana energia que tem sua produção superior aos cultivares convencionais além de ser flexível menos exigente em fertilidade.

\section{REFERÊNCIAS}

1. Saath KCO, Fachinello AL. Crescimento da demanda mundial de alimentos e restrições do fator terra no Brasil. Rev Econ Sociol Rural. 2018;56(2):195-212. doi: http://dx.doi.org/10.1590/1234-56781806-94790560201.

2. Instituto Brasileiro de Geografia e Estatística - IBGE. Estatística da produção pecuária 2018. Rio de Janeiro: IBGE; 2018.

3. Costa KAP, Assis RL, Perim RC, Guimarães KC, Paludo A, Privado CJT, et al. Qualidade e valor nutritivo de silagem de genótipos de milheto produzidas com e sem inoculante bacteriano. Rev Bras Saude Prod Anim. 2011;12(2):286-95.

4. Luz LA, Rodrigues PHM, Souza WD, Santos MER, Silva SP. Acúmulo de forragem do capim-marandu diferido com alturas variáveis. Enciclopedia Biosfera. 2015;11(21):2335 .

5. Martins SCSG, Carvalho GGP, Pires AJV, Silva RR, Leite LC, Pereira FM, et al. Qualitative parameters of sugarcane silages treated with urea and calcium oxide. Semin Cienc Agrar. 2015;36(2):1135-44.

6. Rocha WJB, Rocha Júnior VR, Reis ST, Palma MNN, Oliveira LM. Cinética de fermentação ruminal da matéria seca e dos carboidratos de silagens de cana-de-açúcar com aditivos. Rev Caatinga. 2015;28(1):228-38.

7. Arcoverde SNS, Souza CMA, Orlando RC, Silva MM, Nascimento JM. Crescimento inicial de cultivares de cana-se-açucar em plantio de inverno sob preparos conservacionistas do solo. Rev Eng Agric. 2019;27(2):142-56.

8. Matsuoka S, Kennedy AJ, Santos EG, Tomazela AL, Rubio LC. Energy cane: its concept, development, characteristics, and prospects. Adv Bot. 2014:1-13. doi: http://dx.doi.org/10.1155/2014/597275.

9. Freitas AWP, Pereira JC, Rocha FC, Detmann E, Ribeiro MD, Costa MG, et al. Características da silagem de cana-de-açúcar tratada com inoculante bacteriano e hidróxido de sódio e acrescida de resíduo da colheita de soja. Rev Bras Zootec. 2006;35(1):48-59. doi: http://dx.doi.org/10.1590/S1516-35982006000100006. 
10. Martins JC, Silva ALP. Estacionalidade e planejamento forrageiro. Cienc Biotecnol Saude. 2015;(12):86-8.

11. Freitas PVDX, Tomazello DA, Ribeiro FM, Oliveira JFA, Lopes AR, Almeida EM, et al. Efeitos do pastejo no desenvolvimento e crescimneto de plantas forrageiras. Rev Cient Rural. 2019;21(2):388-405. doi:https://doi.org/10.30945/rcr-v21i2.2776.

12. Nascimento MCO, Souza BB, Silva FV, Melo TS. Armazenamento de forragem para caprinos e ovinos no semiárido do nordeste. Agropecu Cient Semiarido. 2013;9(4):20-7.

13. Pedroso AF, Rodrigues AA, Barioni Júnior W, Barbosa PF, Santos FAP, Nussio LG. Aditivos químicos e inoculante bacteriano na ensilagem de cana-de-açúcar: efeitos sobre a fermentação das silagens e o desempenho de garrotes. Rev Bras Zootec. 2011;40(6):1181-7. doi:http://dx.doi.org/10.1590/S1516-35982011000600004.

14. Rosseto RA. Bioenergia, a cana energia e outras culturas energeticas. Pesqui Tecnol. 2012;9(1):1-6.

15. Shields S, Booapathy R. Ethanol production from lignocellulosic biomass of energy cane. Int Biodeterior Biodegradation. 2011;65:142-146. doi:10.1016/j.ibiod.2010.10.006.

16. Paiva L. Cana energia e realidade. Cana Online. 2015;24:48-67.

17. Thammasittirong SN, Chatwachirawong P, Chamduang T, Thammasittirong A. Avaliação da produção de etanol a partir de açúcar e parte lignocelulósica da cana-de-energia. Ind Crop Prod. 2017;108:598-603. doi:https://doi.org/10.1016/j.indcrop.2017.07.023.

18. Nussio LG, Campos FP, Paziani SF, Santos FAP. Volumosos suplementares estratégica de decisão e utilização. In: Evangelista AR, Silveira PJ, Abreu JG, editors. Forragicultura e pastagens: temas em evidência. Lavras: Editora UFLA; 2002. p.193-232.

19. Silva SC. A cana-de-açúcar como alimento volumoso suplementar. In: Peixoto AM, Moura JC, Faria VP, editors. Volumosos para bovinos. Piracicaba: FEALQ; 1993. p.5974.

20. Pinho RMA, Santos EM, Rodrigues JAS, Macedo CHO. Avaliação de genótipos de milheto para silagem no semiárido. Rev Bras Saude Prod Anim. 2013;14(3):426-36.

21. Van Soest PJ. Limiting factor sinplant residu e soflow bio degradability. Agric Environ. 1981;6:135-43.

22. Pedroso AF, Nussio LG, Loures DRS, Paziani SF, Igarasi MS, Coelho RM, et al. Efeito do tratamento com aditivos químicos e inoculantes bacterianos nas perdas e na qualidade de silagens de cana-de-açúcar. Rev Bras Zootec. 2007;36(3):558-64. doi: http://dx.doi.org/10.1590/S1516-35982007000300006.

23. Carvalho FAL, Queiroz MAA, Silva JG, Voltolini TV. Fermentative characteristics in sugarcane silage with maniçoba. Cienc Rural. 2014;44(11):2078-83. doi: 10.1590/0103$8478 \mathrm{cr} 20131471$. 
24. Cardoso EG, Silva JM. O que é silagem? [Internet]. Campo Grande: Embrapa Gado de Corte; 2007 [cited 2019 Ago 30]. Available from: http://www.agroredenoticias.com.br/textos.aspx?htUpTLaCxzs//NiXdoozAg

25. Mcdonald P, Henderson AR, Heron SJE. The biochemistry of silage. 2nd ed. Marlow: Chalcombe Publications; 1991.

26. Nunes CS, Baptista AO. Implicações da reação de Maillard nos alimentos e nos sistemas biológicos. Rev Port Cienc Vet. 2001;96(538):53-9.

27. França AMS, Ferreira IC, Hermisdorff IC, Mendonça EP, Fernandes EA, Rossi DA. Dinâmica química, microbiológica e física da silagem de farelo úmido de glúten de milho. Cienc Rural. 2015;45(4):684-9. doi:http://dx.doi.org/10.1590/0103$8478 \mathrm{cr} 20140716$.

28. Vasconcelos WA, Santos EM, Zanine AM, Pinto TF, Lima WC, Edvan RL, et al. Valor nutritivo de silagens de capim-mombaça (Panicum maximum Jacq.) colhido em função de idades de rebrotação. Rev Bras Saude Prod. 2009;10(4):874-84.

29. Van Soest PJ. Nutritional ecology of the ruminant. 2nd ed. Ithaca: Cornell University Press; 1994.

30. Lima-Júnior DM, Rangel AHN, Urbano SA, Oliveira JPF, Maciel MV. Silagem de gramíneas tropicais não-graníferas. Agropecu Cient Semiarido. 2014;10(2):1-11.

31. Monteiro IJG, Abreu JGD, Cabral LDS, Ribeiro MD, Reis RHPD. Silagem de capimelefante aditivada com produtos alternativos. Acta Sci Anim Sci. 2011;33(4):347-52. doi: 10.4025/actascianimsci.v33i4.12629.

32. Bernardes TE. Levantamento das práticas de produção e uso de silagens em fazendas de leite no Brasil. Lavras: Milkpoint, UFLA; 2012.

33. Pedroso AF, Nussio LG, Paziani SF, Lourdes DRS, Igarasi MS, Coelho RM, et al. Fermentation and epiphytic microflora dynamics in sugar cane silage. Sci Agric. 2005;62(5):427-32. doi: http://dx.doi.org/10.1590/S0103-90162005000500003.

34. Siqueira GR, Reis RA, Schocken-Iturrino RP, Pires AJV, Bernardes TF, Amaral RC. Perdas de silagens de cana-de-açúcar tratadas com aditivos químicos e bacterianos. Rev Bras Zootec. 2007;36(6):2000-9. doi: 10.1590/S1516- 35982007000900008.

35. Castro-Neto AG, Molina LR, Gonçalves LC, Jayme CG. Parâmetros de fermentação de silagens de cana-de-açúcar submetidas a diferentes tratamentos. Arq Bras Med Vet Zootec. 2008;60(5):1150-6.

36. Pedroso AF, Nussio LG, Barioni-Júnior W, Rodrigues AA, Lourdes DRS, Campos F, et al. Performance of holstein heifers fed sugarcane silages treated with urea, sodium benzoate or Lactobacillus buchneri. Pesqui Agropecu Bras. 2006;41(4):649-54. doi: http://dx.doi.org/10.1590/S0100-204X2006000400015. 
37. Santos MC, Nussio LG, Mourão GB, Schmidt P, Mari LJ, Ribeiro JL, et al. Nutritive value of sugarcane silage treated with chemical additives. Sci Agric. 2009;66(2):159-63. doi: http://dx.doi.org/10.1590/S0103-90162009000200003.

38. Amaral RC, Pires AV, Susin I, Nussio LG, Mendes CQ, Gastaldello Júnior AL. Cana-deaçúcar ensilada com ou sem aditivos químicos: fermentação e composição química. Rev Bras Zootec. 2009;38(8):1413-21. doi: http://dx.doi.org/10.1590/S151635982009000800004.

39. Loures DRS, Nussio LG, Paziani SF, Pedroso AF, Mari LJ, Ribeiro JL, et al. Chemical composition and effluent yield of Tanzaniagrass silages affect end by wilting, particle size and enzymatic/microbial additive. Rev Bras Zootec. 2005;34(3):726-35. doi: 10.1590/S1516-35982005000300003.

40. Dias AM, Ítavo LCV, Blan LR, Gomes ENO, Soares CM, Leal ES, et al. Ureia e glicerina bruta como aditivos na ensilagem de cana-de-açúcar. Arq Bras Med Vet Zootec. 2014;66(6):1874-81. doi:http//dx.doi.org/10.1590/1678-7349.

41. Alli I, Fairbairn R, Baker BE. The effects of ammonia on the fermentation of chopped sugarcane. Anim Feed Sci Technol. 1983;9(4):291-9. doi: https://doi.org/10.1016/03778401(83)90022-6.

42. Nussio LG, Susin I, Mendes CQ, Amaral RC. Estratégias para garantir eficiência na utilização de cana-de-açúcar para ruminantes. Tecnol Cienc Agropecu. 2009;3(4):27-33.

Recebido em: 16/08/2020 Aceito em: 04/12/2020 